\title{
The distribution of the fathead sculpin species Cottunculus subspinosus Jensen, 1902
}

\author{
Ingvar Byrkjedal', Gunnar Langhelle', Jorgen Schou Christiansen² and Oleg V. Karamushko ${ }^{3}$
}

Byrkjedal I, Langhelle G, Christiansen JS and Karamushko OV. 2018. The distribution of the fathead sculpin species Cottunculus subspinosus Jensen, 1902. Fauna norvegica 38: 13-17.

The range of the rarely caught fathead sculpin species Cottunculus subspinosus has been considered restricted to the waters off East Greenland and Northeast Iceland. For the first time the species is recorded from the east side of the Norwegian Sea, and also it is found further north in the Greenland Sea than previously known. Mapping all the corroborated specimens known indicates that the species seems confined to the continental slopes of the Nordic Seas, where it is found in waters with a temperature below zero and a depth of more than $900 \mathrm{~m}$. Depth distribution shows almost no overlap with the closely related sympatric Cottunculus microps, perhaps as a result of competitive exclusion.

doi: 10.5324/fn.v38i0.2381. Received: 2017-10-04. Accepted: 2018-02-18. Published online: 2018-04-13. ISSN: $1891-5396$ (electronic).

Keywords: Cottoidei; Arctic; range; interspecific competition

1. Department of Natural History, University Museum of Bergen, University of Bergen, N-5020 Bergen, Norway

2. Department of Arctic and Marine Biology, Faculty of Biosciences, Fisheries and Economics, UiT The Arctic University of Norway, Tromsø, Norway

3. Murmansk Marine Biological Institute, Kola Scientific Centre, Russian Academy of Sciences, ul. Vladimirskaya 17, Murmansk, 183010 Russia

Corresponding author: Ingvar Byrkjedal

E-mail:ingvar.byrkjedal@uib.no

\section{INTRODUCTION}

The family Psychrolutidae (Scorpaeniformes: Cottoidei) consists of 8 genera and about 38 species, which are more or less tadpole-shaped, limp, and scale-less (Nelson et al. 2016) and live in the benthic zone from shallow waters to $2800 \mathrm{~m}$ depth (Fedorov \& Nelson 1986). In the North-eastern Atlantic two species occur in the arctic and subarctic part of the ocean, one of which, Cottunculus microps Collett, 1875, is common and widespread, while the other one, Cottunculus subspinosus Jensen, 1902, is known from only a few specimens (Fedorov \& Nelson 1986, Mecklenburg et al. 2011, Byrkjedal et al. 2014). C. subspinosus has frequently been placed in the genus Psychrolutes, but its inclusion in Cottunculus is now strongly supported by DNA sequencing (Mecklenburg et al. 2018).

C. subspinosus was first described from four specimens caught off northeast Iceland by the Ingolf Expedition in 1895-
1896 (Lütken 1898; Jensen 1902) and these remained the only known specimens until 1989, when additional nine specimens were caught off eastern Greenland by the Shinkai Maru expedition (Møller et al. 2010). Subsequently, the species has been reported from Northeast Greenland, Iceland and near Jan Mayen Island (Christiansen 2003; Fossum et al. 2012; Jónsson \& Pálsson 2013).

A few more specimens have been caught by recent research cruises, and especially one of them extends the known distribution of this species in the Nordic Seas considerably. The latest range map published for the species is that of Jónsson \& Pálsson (2013). From the new records and a re-examination of the earlier published ones the present paper aims to draw a more complete and accurate picture of the geographic and spatial distribution of $C$. subspinosus. With possible interspecific competition in mind, a comparison of its depth distribution 
is made with that of the morphologically similar sympatric psychrolutid species $C$. microps.

\section{MATERIAL AND METHODS}

The paper is based on unpublished material recently brought to the University Museum of Bergen, a re-examination of published records (Christiansen 2003; Møller et al. 2010; Fossum et al. 2012; Jónsson \& Pálsson 2013), and an online search of records entered in Global Biodiversity Information Facility (GBIF; http://www.gbif.org/).

The unpublished material was obtained from the TUNUIV Expedition (R/V 'Helmer Hanssen', August 2010) and the MAREANO project (R/V 'G.O. Sars', May 2012), the latter a project run by the Institute of Marine Research, Bergen, aiming to map benthic organisms off the Norwegian coast (www.mareano.no). The TUNU expedition used a Campelen 1800/96 NOFI bottom trawl with $49 \mathrm{~m}$ wing spread and a cod-end of $22 \mathrm{~mm}$ mesh size towed for $22 \mathrm{~min}$ at a speed of 2.4 knots, and the fish were frozen on board for final preservation and storage at the University Museum of Bergen. The MAREANO used a beam trawl with an opening of $2 \times 2$ $\mathrm{m}$ and a $4 \mathrm{~mm}$ mesh size, towed on the bottom for $5 \mathrm{~min}$ at a speed of 1 knot. The fish caught by this project (one specimen) was fixed in formalin on board, and final species identification was done at the museum as the material was transferred to $75 \%$ ethanol for permanent storage.

Circumstances of previously published catches were described by Lütken (1898), Knudsen (1899) and Fossum et al. (2012), and the Shinkai Maru expeditions in Greenland waters by Okamura et al. (1995). The species was, however, not mentioned by Okamura et al. (1995), yet it did appear in the Shinkai Maru material brought to the Zoological Museum, University of Copenhagen (Møller et al. 2010 and pers. comm.). Judged from date and coordinates two specimens in the Zoological Museum, University of Alberta, almost certainly originated from one of the Shinkai Maru stations, but this has not been possible to confirm.

The depth distribution of $C$. subspinosus was based on data from specimen labels, and compared to that of $C$. microps from a material ranging from East Greenland to Svalbard and the Barents Sea, held in the collections of the University Museum of Bergen. In cases where depth at a trawl station was available as a maximum-minimum interval, the median value was used in calculations.

\section{RESULTS}

Cottunculus subspinosus is presently known to science from 14 geographic locations, comprising 48 specimens, of which 28 are permanently preserved and kept in scientific collections (Table 1, Figure 1). A majority of the locations (11) are on the

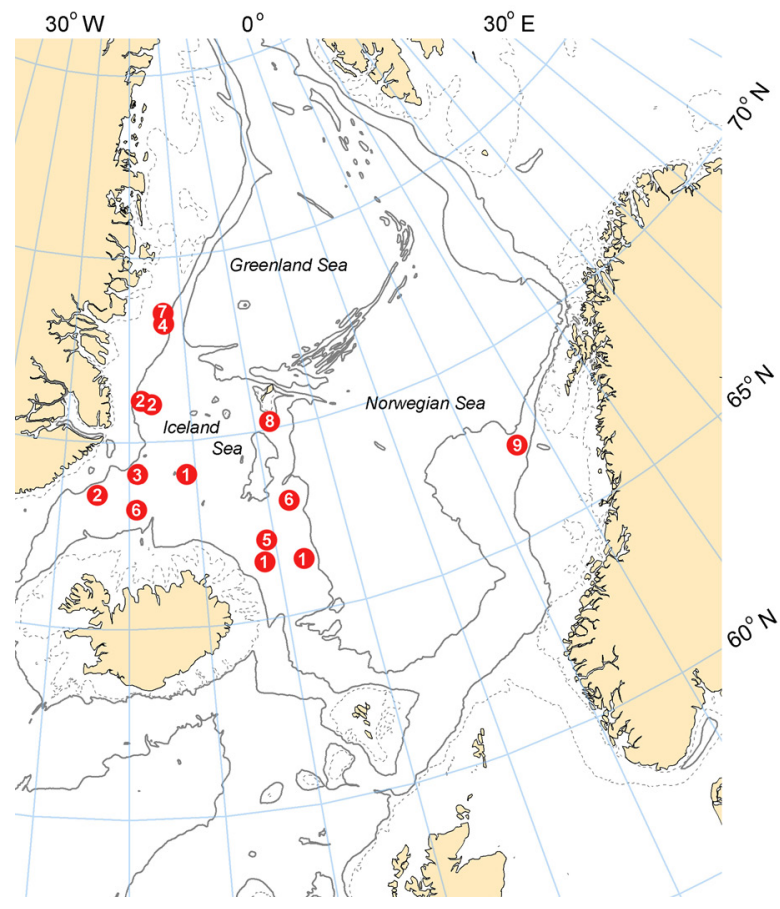

Figure I. Known locations of Cottunculus subspinosus. Sources: 1 = Lütken (1898); Knudsen (1899); Jensen (1902). 2 = Zoological Museum, University of Copenhagen. $3=$ Zoological Museum, University of Alberta. $4=$ Christiansen (2003). $5=$ Swedish Museum of Natural History, Stockholm. 6 = Jónsson \& Pálsson (2013); Pálsson pers. comm. 7 = this study TUNU-IV Expedition. $8=$ Fossum et al. (2012). $9=$ this study MAREANO project. Further details in Table 1. The Greenland, Iceland and Norwegian Seas comprise the Nordic Seas.

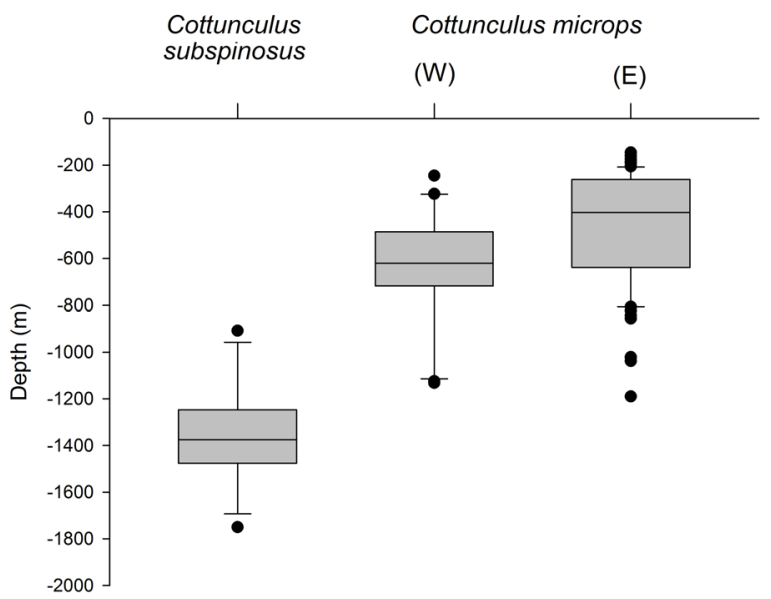

Figure 2. Depth distribution of Cottunculus subspinosus locations ( $\mathrm{n}=14$ locations) compared to that of $C$. microps in northeastern Greenlandic waters (West, 'W'; $\mathrm{n}=23$ locations) and in the Barents Sea - Svalbard region (East, 'E'; $\mathrm{n}=80$ locations). Data for $C$. microps are from specimens held in the collections of the University Museum of Bergen. Median depths shown by horizontal bar, upper and lower quartiles by boxes, 95 percentiles by whiskers, and extremes by dots. 


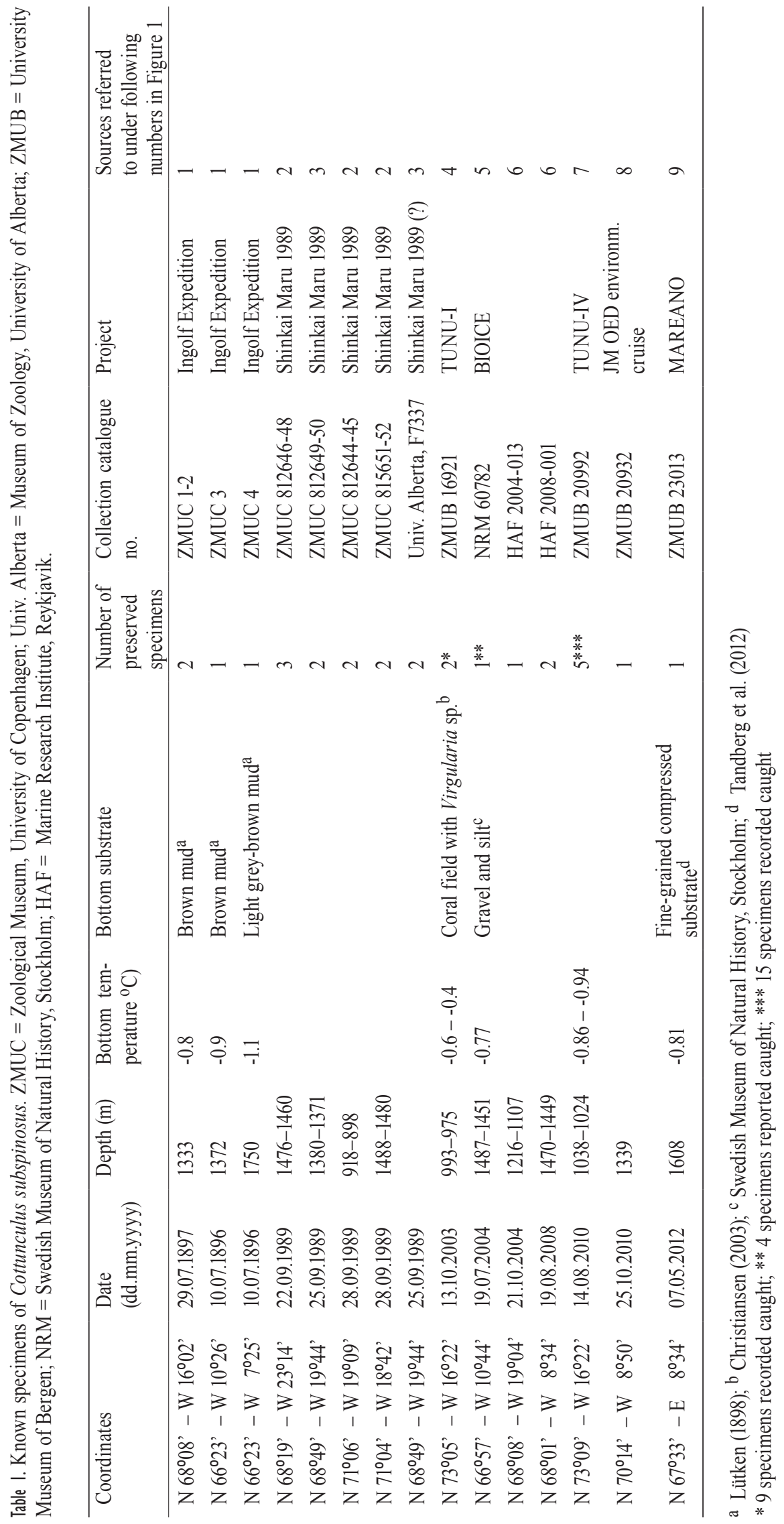


slopes surrounding the sea north of Iceland (Iceland Sea, sensu Blindheim 2004) while two are on the southwestern slope of the Greenland Sea and one on the eastern slope of the Norwegian Sea.

Depth distributions are known for all locations (Table 1), ranging from about $900 \mathrm{~m}$ to $1750 \mathrm{~m}$, with most of the catches between 1300 and $1500 \mathrm{~m}$ (Figure 2). The depth distribution of $C$. subspinosus vs. C. microps shows a clear-cut segregation in the realised habitat for the two sympatric psychrolutids. $C$. subspinosus inhabits the deeper slopes, whereas $C$. microps is confined to waters of less depths $(245-1090 \mathrm{~m})$. The depth distribution of $C$. microps in the Greenland Sea region, where it could have gone far deeper, is the same as in the shallower Barents Sea (Figure 2). Bottom temperatures were available for seven of the $C$. subspinosus locations and all of them had subzero waters, ranging from $-0.4--1.1^{\circ} \mathrm{C}$ (Table 1).

Information on bottom substrate was available for six locations (Table 1). Fine-grained substrate was generally found, either as soft mud or as more firmly compressed substrate. Mud and gravel was recorded at one location and coral fields (with Virgularia sp.) at another. The easternmost location had a bottom fauna dominated by fanworms (Sabellidae) on the more compressed substrate found there.

\section{DISCUSSION}

The present study substantiates that C. subspinosus is distributed in the deep and cold waters along the continental slopes of the northeast Atlantic Ocean. The species has not been documented outside the Nordic Seas, contra map shown by Jónsson \& Pálsson (2013) which extends the distribution along SE Greenland south of Denmark Strait.

The record on the eastern side of the Norwegian Sea extends the known range of C. subspinosus considerably, about $730 \mathrm{~km}$ eastward from the previously known locality nearest to it. The Psychrolutidae primarily comprises species with demersal eggs and a sedentary benthic life form (Fedorov \& Nelson 1986), and it is unlikely that $C$. subspinosus undertakes long-distance migrations. The occurrence of the species on the Norwegian slopes is therefore probably not due to recent colonisation.

From the present records we would expect $C$. subspinosus to be continually distributed along the deeper slopes surrounding the Norwegian Sea, but to verify that, the species will have to be looked for on the northern slopes of the Iceland-Faroes-Norway Ridge, for which there presently is a hiatus in the documented range. Also, we do not know if the range extends to the deep plains of the Nordic Seas, which do have temperatures below zero (Blindheim 2004). Furthermore, the northern limit of the species' range has probably not yet been established in spite of many years of fisheries research carried out in the western part of the Barents Sea and around Svalbard (e.g., Wienerroither et al. 2011). Most of that sampling has probably not been deep enough for the species to be obtained. Future sampling deeper than $1000 \mathrm{~m}$ in those waters would be needed. However, the species was not observed by Soltwedel et al. (2009) during samplings at the slope from Vestnesa Ridge (1650 m depth) to the Molloy Hole $\left(5500 \mathrm{~m}\right.$ depth) at about $79^{\circ} \mathrm{N}$ west of Spitsbergen.

With almost no overlap, the depth range of $C$. subspinosus succeeds that of the sympatric and common $C$. microps. The two species are morphologically very similar, and the distinct depth segregation could be a result of competitive exclusion. After all, the number of specimens caught on two of the trawl stations off NE Greenland ( 9 and 15 individuals, Table I) indicates that $C$. subspinosus might be abundant in places. Usually, C. microps occurs in no higher numbers in bottom trawl hauls even in areas where it is considered common: 111 specimens of $C$. microps caught in 60 hauls (gear and towing time similar to the Greenland samplings) distributed over western Barents Sea (Byrkjedal \& Høines 2007), gave median, as well as upper quartile numbers, of only 2 specimens per station, and a maximum of 6 . However, because $C$. subspinosus is known from so few specimens, details about its feeding ecology and life history are virtually unknown (Fedorov \& Nelson 1986). The two species are apparently also adapted to different temperatures, with C. subspinosus found solely in subzero waters and C. microps (Byrkjedal \& Høines 2007) chiefly in temperatures above zero, and this could also explain their difference in depth distribution. In the North-western Atlantic C. microps overlaps in distribution with Cottunculus thomsonii (Günther, 1882) in Baffin Bay - Davis Strait. Here these two species seem not to be depth-segregated, but $C$. thomsonii is found in somewhat warmer water than C. microps (Coad \& Reist 2018).

\section{ACKNOWLEDGEMENTS}

We would like to thank Peter D.R. Møller for information on C. subspinosus in the collections of Zoological Museum, Copenhagen. We are also very grateful to Jamie Maclaine, Natural History Museum, London, for information on the species identity of the specimens of their catalogue number 1981.3.16.569-570, and to Jónbjörn Pálsson, Marine Research Institute, Reykjavik, for giving us access to the specimens caught by Icelandic vessels. Swedish Museum of Natural History kindly sent us their only specimen of this species (NRM 60782) on loan. We are indebted to Guðmundur Guðmundsson, Natural History Museum of Iceland, for providing information about Icelandic fish collections, and Alison Murray, University of Alberta for information about two specimens in their collections. We also thank the personnel of the MAREANO project for collecting specimens and Katrine Kongshavn for securing these for the collections of the University Museum of Bergen. We are also very grateful to two anonymous reviewers for useful comments on the manuscript. This study forms part of the TUNU-Programme, UiT The Arctic University of Norway. 


\section{REFERENCES}

Blindheim, J. 2004. Oceanography and climate. In Skjoldal HR (ed). The Norwegian Sea ecosystem. Trondheim, Tapir Academic Press. pp. 65-96.

Byrkjedal I, Hadler-Jacobsen S, Rees D and Orlov, A. 2014. Molecular and morphological variation in saddled fathead sculpins (Psychrolutidae: Cottunculus) of the north-east Atlantic Ocean, with a synonymy of three species. Journal of Fish Biology 85: 821-837. doi: 10.1111/jfb.12458

Byrkjedal I and Høines A. 2007. Distribution of demersal fishes in the western Barents Sea. Polar Research 26: 135-151. doi: 10.1111/j.1751-8369.2007.00030.x

Christiansen JS. 2003. TUNU-I Expedition: The fish fauna of the NE Greenland fjord systems. Danmarkshavn $\left(77^{\circ} \mathrm{N}\right)-$ Eskimonæs $\left(74^{\circ} \mathrm{N}\right) 2^{2}-16$ October 2003. Technical Report. http:// bioold.science.ku.dk/jfsteffensen/tunu-1-report.pdf

Coad BW \& Reist JD. 2018. Marine fishes of Arctic Canada. Toronto, University of Toronto Press. $618 \mathrm{p}$.

Fedorov VV and Nelson JS. 1986. Psychrolutidae. In Whitehead PJP, Bauchot M-L, Hureau J-C, Nielsen J and Tortonese E (eds) Fishes of the North-eastern Atlantic and the Mediterranean. Paris, UNESCO. pp. 1241-1268.

Fossum P, Mork KA, Tverberg V, Boitsov S, Heldal HE, Bagøien E, Rønning J, Slotte A, Vollen T, Wienerroither R, Dahle G, Buhl-Mortensen P, Øien N, Øigård TA and Fauchald P. 2012. Description of the marine environment and resources in the sea areas close to Jan Mayen. Rapport fra Havforskningen 16: 1-119. (Norwegian, English title and summary.)

Jensen AS. 1902. Ichtyologiske studier. Videnskabelige meddelelser fra den Naturhistoriske Forening i Kjøbenhavn for Aaret 1901: 191-215.

Jónsson G and Pálsson J. 2013. Íslenskir fiskar. Reykjavik, Mál og menning. 493 pp.

Knudsen M. 1899. Hydrography. The Danish Ingolf-expedition 1(2): 23-161.

Lütken IC. 1898. The ichthyological results. The Danish Ingolfexpedition 2(1): 1-39.

Mecklenburg CW, Møller P R and Steinke D. 2011. Biodiversity of Arctic marine fishes: taxonomy and zoogeography. Marine Biodiversity 41: 109-140; Online Resource 1: List of Fishes occurring in Arctic marine waters, with notes on new records and patterns of distribution. doi: 10.1007/s12526-010-0070-Z

Mecklenburg CW, Lynghammar A, Johannesen E, Byrkjedal I, Christiansen JS, Dolgov AV, Karamushko OV, Mecklenburg TA, Møller PR, Steinke D and Wienerroither RM. 2018. Marine fishes of the Arctic region. Reykjavik, Conservation of Arctic Fauna and Flora. 739 p.

Møller PR, Nielsen JG, Knudsen SW, Poulsen JY, Sünksen K and Jørgensen OA. 2010. A checklist of the fish fauna of Greenland waters. Zootaxa 2378: 1-84.

Nelson JS, Grande TC and Wilson MVH. 2016. Fishes of the World. Hoboken (NJ), John Wiley \& Sons. 707 p.

Okamura O, Amaoka K, Takeda M, Yano K, Okada K and Chikuni, S. 1995. Fishes collected by the R/V Shinkai Maru around Greenland. Tokyo, Japan Marine Fishery Resource Center. 304 p.

Soltwedel T, Jaeckisch N, Ritter N, Hasemann C, Bergmann M and Klages M. 2009. Bathymetric patterns of megafaunal assemblages from the arctic deep-sea observatory HAUSGARTEN. DeepSea Research I 56: 1856-1872. doi: 10.1016/j.dsr.2009.05.012

Tandberg AH, Holte B and Buhl-Mortensen P. 2012. MAREANO toktrapport 2012. Toktrapport Havforskningsinstituttet 8-2012: $1-38$.

Wienerroither R, Johannesen E, Dolgov A, Byrkjedal I, Bjelland O, Drevetnyak K, Eriksen KB, Høines Å, Langhelle G, Langøy H, Prokhorova T, Prozorkevich D and Wenneck T de L. 2011. Atlas of the Barents Sea Fishes. IMR/PINRO Joint Report Series 1-2011: 1-272.

Editorial responsibility: Torkild Bakken.

This article is open-access and distributed under the terms of the Creative Commons Attribution 4.0 International license. This permits all non-commercial use, distribution, and reproduction in any medium, provided the original work is properly cited. (http://creativecommons.org/licenses/by/4.0/). 